\title{
Public Knowledge of Hand Sanitizers and Disinfectants in Saudi Arabia
}

\author{
Yousef Ahmed Alomi* iD, BSc. Pharm, \\ MSc. Clin Pharm, BCPS, BCNSP, DiBA, CDE, \\ Critical Care Clinical Pharmacists, TPN \\ Clinical Pharmacist, Freelancer Business \\ Planner, Content Editor and Data Analyst, \\ Riyadh, SAUDI ARABIA. \\ Basmah Sulimain AlHamdan, \\ Senior Quality Specialist, King Fahad \\ Medical City, Riyadh, SAUDI ARABIA. \\ Amani Abdullah Bahdailah, \\ Pharmaceutical Care Services, King \\ Abdullah Bin Abdulaziz University \\ Hospital, Riyadh, SAUDI ARABIA \\ Sahar Obaid Alosaimi, \\ College of Pharmacy, Taif University, Taif, \\ SAUDI ARABIA. \\ Deema Abdullah Altuwayhir, \\ College of Dentistry, Hail University, Hail, \\ SAUDI ARABIA
}

\section{Correspondence:}

Dr. Yousef Ahmed Alomi, BSc. Pharm MSc. Clin Pharm, BCPS, BCNSP, DiBA, CDE, Critical Care Clinical Pharmacists, TPN Clinical Pharmacist, Freelancer Business Planner, Content Editor and Data Analyst, Riyadh 11392, Riyadh, Saudi Arabia.

Phone no: +966504417712

E-mail: yalomi@gmail.com
Received: 04-02-2021;

Accepted: 22-04-2021.

Copyright: (c) the author(s),publisher and licensee Pharmacology, Toxicology and Biomedical Reports. This is an open-access article distributed under the terms of the Creative Commons Attribution NonCommercial License, which permits unrestricted non-commercial use, distribution, and reproduction in any medium, provided the original work is properly cited.

This is an open access article distributed under the terms of the Creative Commons AttributionNonCommercial-ShareAlike 4.0 License

Access this article online

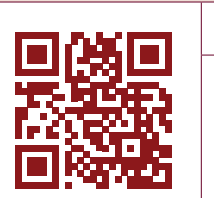

www.ptbreports.org

DOI:

10.5530/PTB.2021.7.15

\begin{abstract}
Objectives: Hand sanitizers and disinfectants have been commonly used during epidemic and pandemic situations. Despite the proven efficacy and safety of sanitizers and disinfectants, the publics' knowledge about their use is still controversial. In this survey, we aimed to investigate the knowledge of the public about the use of hand sanitizer and disinfectants in the Kingdom of Saudi Arabia. Design and Setting: A self-administered structured questionnaire was sent to the public via online mode. It collected demographic information and collected information about different hand sanitizers and disinfectants and their general knowledge on such products, contraindications, and storage information during the COVID-19 pandemic. Data were collected through the Survey monkey program. Results: A total of 402 participants responded to the questionnaire. Of them, $32.58 \%$ were from the western region, and $25.76 \%$ were from the central area, and there were statistically significant differences between different regions ( $p=0.000$ ). Based on nationality, $90.88 \%$ of Saudi nationals responded to the questionnaire. In addition, $65.17 \%$ of the responders were female, with statistically significant differences $(p=0.000)$. The most prevalent age group was between 18 and 29 years $(50.25 \%)$, with statistically significant differences between all age groups $(p=0.000)$. The average general knowledge score was 3.90 emphasizing the medication administration (4.40) and frequency of usage (4.25). The average score of contraindication knowledge was 2.91. The feature most known by the public was the general side reaction that appears during use (3.21), and usage of the medication with other drugs is forbidden (3.04). The average score for the knowledge of storage was 3.45. The part most known by the patient was the storage of the sanitizer or disinfectant at room temperature (3.91) and sanitizer or disinfectant prices in general (3.58). Conclusion: The knowledge about storage of sanitizers and disinfectants among the public in Saudi Arabia was satisfactory; however, the knowledge about contraindications was insufficient. Therefore, we recommend increasing the general public's awareness about sanitizers and disinfectants in the Kingdom of Saudi Arabia.

Key words: Public, Knowledge, Sanitizer, Disinfectants, Saudi Arabia.
\end{abstract}

\section{INTRODUCTION}

Over the past two years, worldwide, all countries have been affected by the pandemic called COVID-19. ${ }^{1,2}$ Various preventive measures and treatment guidelines were released from various national and international healthcare organizations. $^{3-5}$ One of the common recommendations by these organizations was to use hand sanitizer and disinfectant, ${ }^{2,6,7}$ which are used to prevent the transmission of COVID- 19. Moreover, various medical and pharmaceutical societies released some instructions dealing with sanitizer and disinfectant shortages. Despite frequent usage, the main question is about the magnitude of public knowledge of hand sanitizer and disinfectants. ${ }^{6,9}$ They consisted of generic names, trade names, indications, contraindications, and storage of sanitizer and disinfectant..$^{8-11}$ The active ingredient in most of the sanitizers was alcohol (60-70\%). In addition, the disinfectants contained other chemicals such as phenol-based compound, a chlorinebased compound, and quaternary ammonium salts. $^{8-12}$ Various studies have discussed the knowledge of healthcare professionals with regard to infection control, including the use of sanitizer and disinfectants. ${ }^{13-21}$ However, most of the studies conducted in a non-public and nonCOVID-19 period did not emphasize sanitizer and disinfectants usage. However, few studies have discussed the knowledge of the public with regard to the sanitizer and disinfectants during COVID-19. ${ }^{22-24}$ However, to the best of our knowledge, there are no studies conducted about the understanding of sanitizer and disinfectants usage during the COVID-19 pandemic in Saudi Arabia or Middle Eastern countries. Therefore, in this study, we aimed to assess the public knowledge of sanitizer and disinfectants in Saudi Arabia.

\section{MATERIALS AND METHODS}

A quantitative, cross-sectional electronic survey was performed in Saudi Arabia through a selfadministered questionnaire distributed to the general public over four months. All Saudi citizens were included in this study. Incomplete responses and responses received from outside Saudi Arabia were excluded from the study. An online self-developed questionnaire validated by an expert reviewer was distributed to the public in Saudi Arabia. The survey consisted of two parts. Part one collected demographic information (location, gender, age, qualification, occupational status, and monthly income). The second part included questions on general 
knowledge, contraindications, and storage information of sanitizer or disinfectants during COVID-19. Moreover, resources of knowledge about hand sanitizer or disinfectants. A 5-point Likert response scale system was used to obtain responses. The survey was distributed based on convenient sampling methods and a calculated number of sample of public responders. The survey was distributed through various social media applications such as WhatsApp and Telegram, as well as via direct face-to-face contact. A reminder message was sent once every 1-2 weeks. Based on the previous literature with unlimited population size, the sample was calculated with the population percentage of $50 \%$, the confidence level of $95 \%, z$ score of 1.96 , the margin of error of $5 \%$, and drop-out rate of $5 \%$. As a result, the calculated sample size was 399 , with the power of study of $80 \% .{ }^{25-27}$ The response rate required for the estimated sample size was $60-70 \% .^{27,28}$ Expert reviewers and pilot testing validated the survey. Various reliability tests such as McDonald's $\omega$, Cronbach's $\alpha$, Guttman's $\lambda 2$, and Guttman's $\lambda 6$ were conducted. The data were collected through the Survey Monkey system and analyzed with Statistical Package of Social Sciences (SPSS), Jeffery's Amazing Statistics Program (JASP), and Microsoft Excel (version 16). We performed descriptive and frequency analysis, the goodness of fit analysis, correlation analysis, and inferential analysis between independent variables. The STROBE (Strengthening the reporting of observational studies in epidemiology statement: guidelines for reporting observational studies) guided the reporting of this study. ${ }^{29-31}$

\section{RESULTS}

A total of 402 participants responded to this online questionnaire. Only participants who completed all the sections in the questionnaire were included. The questionnaire's reliability scores were as follows: McDonald's $\omega$ was 0.916 , Cronbach's a was 0.914 , Guttman's $\lambda 2$ was 0.919 , Guttman's $\lambda 6$ was 0.951 , and Greatest Lower Bound was 0.964 . Out of 402 responders, $32.58 \%$ were from the western region, and $25.76 \%$ were from the central region, with statistically significant differences between different regions $(p<0.001)$. Of the total responders, $90.88 \%$ were Saudi nationals. Females (65.17\%) responded more than males, with statistically significant differences $(p<0.001)$. Based on the age, there were five sub-categories of the responders. The most prevalent age group was between 18 and 29 years $(50.25 \%)$, with statistically significant differences between all age groups $(p<0.001)$. Table 1 shows sociodemographic data in detail. Regarding the responders' education level, $65.67 \%$ had a bachelor's degree, $34.91 \%$ were employed, $34.16 \%$ were students, and $26.18 \%$ were non-employees, with statistically significant differences between all educational levels $(p<0.001)$. Based on the profession, only $36.82 \%$ of the responders were healthcare practitioners, and $78.38 \%$ of these practitioners were pharmacists, with statistically significant differences between disciplines $(p<0.001)$ (Table 2$)$.

Responders were asked to choose a level of general knowledge of sanitizers or disinfectants during COVID-19. These elements of learning are commonly used for patient education. The average score of knowledge was 3.90. The most known part by the responders was how to use the medication (4.40) and frequency of usage (4.25). The part with the least knowledge was the generic name of the drug (3.52) and medication dosage form (3.56), with statistically significant differences between responses $(p<0.001)$ (Table 3$)$. Responders were also asked to choose the level of knowledge among knowledge of contraindications of sanitizers or disinfectants. The average score of knowledge was 2.91. These elements of learning are commonly used for patient education. The feature most known by the responders was the general side reaction that appears during use (3.21), and usage of the medication with other drugs is forbidden (3.04). On the contrary, the part least known to the responders was the deal with sanitizer or disinfectant poisoning (2.75) and the effect of the hand sanitizer or disinfectant during breastfeeding
Table 1: The socio-demographic data of responders to the questionnaire.

\begin{tabular}{|c|c|c|c|}
\hline locations & Response Count & $\begin{array}{c}\text { Response } \\
\text { Percent }\end{array}$ & $p$-value \\
\hline Central area & 102 & $25.76 \%$ & \multirow[t]{5}{*}{0.000} \\
\hline North area & 54 & $13.64 \%$ & \\
\hline South area & 76 & $19.19 \%$ & \\
\hline East area & 35 & $8.84 \%$ & \\
\hline West area & 129 & $32.58 \%$ & \\
\hline Answered question & 396 & & \\
\hline Skipped question & 6 & & \\
\hline Nationality & Response Count & $\begin{array}{c}\text { Response } \\
\text { Percent }\end{array}$ & \\
\hline Saudi & 339 & $90.88 \%$ & \multirow[t]{2}{*}{0.000} \\
\hline Non-Saudi & 34 & $9.12 \%$ & \\
\hline Answered question & 373 & & \\
\hline Skipped question & 29 & & \\
\hline Gender & Response Count & $\begin{array}{c}\text { Response } \\
\text { Percent }\end{array}$ & \\
\hline Male & 140 & $80.45 \%$ & \multirow[t]{2}{*}{0.000} \\
\hline Female & 262 & $19.55 \%$ & \\
\hline Answered question & 402 & & \\
\hline Skipped question & 0 & & \\
\hline Age & Response Count & $\begin{array}{c}\text { Response } \\
\text { Percent }\end{array}$ & \\
\hline$<18$ & 35 & $8.71 \%$ & \multirow[t]{5}{*}{0.000} \\
\hline $18-29$ & 202 & $50.25 \%$ & \\
\hline $30-44$ & 110 & $27.36 \%$ & \\
\hline $45-60$ & 41 & $10.20 \%$ & \\
\hline$>60$ & 14 & $3.48 \%$ & \\
\hline Answered question & 402 & & \\
\hline Skipped question & 0 & & \\
\hline
\end{tabular}

(2.78), with statistically significant differences between the responses $(p<0.001)$ (Table 4).

Next, we analyzed the level of knowledge of storage information of sanitizers and disinfectants. These elements of learning are commonly used for patient education. The average score of knowledge was 3.45. The part most known by the patient was to store the sanitizer or disinfectant at room temperature (3.91) and sanitizer or disinfectant prices in general (3.58). The part with the least knowledge was the insurance coverage of your hand sanitizer (2.79) and insurance coverage of your disinfectant (2.79), with statistically significant differences between responses $(p<0.001)$ (Table 5). Participants were also asked about their sources of information about hand sanitizers or disinfectants. For example, some responders depended on the internet to get information (243 (64.46\%)) and healthcare practitioners (174 (46.15\%)). Followed by The Drug Bulletin (154 (40.85\%)) Relatives and friends 115=6 (30.77\%)) (Table 6).

\section{Factors influencing the Public general knowledge of public about hand sanitizers and disinfectants}

Factors that affected the general knowledge, contraindications, and storage of sanitizer or disinfectant during COVID-19. Using independent samples Kruskal-Wallis test and the Bonferroni correction for multiple 


\begin{tabular}{|c|c|c|c|}
\hline Responder Qualifications & Response Count & Response Percent & $p$-value \\
\hline Doctorate & 8 & $1.99 \%$ & \multirow[t]{8}{*}{0.000} \\
\hline Master's degree & 37 & $9.20 \%$ & \\
\hline Bachelor's degree & 264 & $65.67 \%$ & \\
\hline Diploma & 32 & $7.96 \%$ & \\
\hline High school & 48 & $11.94 \%$ & \\
\hline Intermediate School & 10 & $2.49 \%$ & \\
\hline Primary School & 2 & $0.50 \%$ & \\
\hline Not educated & 1 & $0.25 \%$ & \\
\hline Answered question & 402 & & \\
\hline Skipped question & $\mathbf{0}$ & & \\
\hline Occupational status & Response Count & Response Percent & \\
\hline Employee & 140 & $34.91 \%$ & \multirow[t]{4}{*}{0.000} \\
\hline Non-employee & 105 & $26.18 \%$ & \\
\hline Student & 137 & $34.16 \%$ & \\
\hline Retried & 19 & $4.74 \%$ & \\
\hline Answered question & 401 & & \\
\hline Skipped question & 1 & & \\
\hline $\begin{array}{l}\text { Are you a health care practitioner (Medical Doctor- Dentist- } \\
\text { Pharmacist- Nurse- Others? }\end{array}$ & Response Count & Response Percent & \\
\hline Yes & 148 & $36.82 \%$ & \multirow[t]{2}{*}{0.000} \\
\hline No & 254 & $63.18 \%$ & \\
\hline Answered question & 402 & & \\
\hline Skipped question & $\mathbf{0}$ & & \\
\hline If you are a health care practitioner, you are a & Response Count & Response Percent & \\
\hline Physician & 11 & $7.43 \%$ & \multirow[t]{4}{*}{0.000} \\
\hline Dentist & 9 & $6.08 \%$ & \\
\hline Pharmacist & 116 & $78.38 \%$ & \\
\hline Nurse & 4 & $2.70 \%$ & \\
\hline Other (please specify) & 8 & $5.41 \%$ & \\
\hline Answered question & 148 & & \\
\hline Skipped question & 254 & & \\
\hline
\end{tabular}

\begin{tabular}{|l|c|c|c|c|c|c|c|c|c|c|c|c|}
\hline Table 3: The General knowledge of sanitizer or disinfectant during used covid-19. \\
\hline
\end{tabular}




\begin{tabular}{|c|c|c|c|c|c|c|c|c|c|c|c|c|c|}
\hline \multirow{2}{*}{$\begin{array}{l}\text { Use your medications } \\
\text { with diseases are } \\
\text { forbidden }\end{array}$} & \multicolumn{2}{|c|}{$\begin{array}{c}\text { Complete } \\
\text { information }\end{array}$} & \multicolumn{2}{|c|}{$\begin{array}{l}\text { Incomplete } \\
\text { information }\end{array}$} & \multicolumn{2}{|c|}{$\begin{array}{c}\text { Weak } \\
\text { information }\end{array}$} & \multicolumn{2}{|c|}{$\begin{array}{l}\text { I do not have } \\
\text { information }\end{array}$} & \multicolumn{2}{|c|}{$\begin{array}{l}\text { I do not need } \\
\text { this information }\end{array}$} & \multirow{2}{*}{$\begin{array}{c}\text { Total } \\
477\end{array}$} & \multirow[b]{2}{*}{3.02} & \multirow{2}{*}{$\begin{array}{c}p \text {-value } \\
0.000\end{array}$} \\
\hline & 79 & $16.56 \%$ & 135 & $28.30 \%$ & 80 & $16.77 \%$ & 83 & $17.40 \%$ & 100 & $20.96 \%$ & & & \\
\hline $\begin{array}{l}\text { Usage the medication } \\
\text { with other drugs are } \\
\text { forbidden }\end{array}$ & 85 & $17.93 \%$ & 131 & $27.64 \%$ & 76 & $16.03 \%$ & 83 & $17.51 \%$ & 99 & $20.89 \%$ & 474 & 3.04 & 0.000 \\
\hline $\begin{array}{l}\text { General side reaction } \\
\text { that appear during use }\end{array}$ & 85 & $18.44 \%$ & 141 & $30.59 \%$ & 96 & $20.82 \%$ & 65 & $14.10 \%$ & 74 & $16.05 \%$ & 461 & 3.21 & 0.000 \\
\hline $\begin{array}{l}\text { The effect of your } \\
\text { medications during } \\
\text { pregnancy }\end{array}$ & 69 & $13.83 \%$ & 127 & $25.45 \%$ & 64 & $12.83 \%$ & 105 & $21.04 \%$ & 134 & $26.85 \%$ & 499 & 2.78 & 0.000 \\
\hline $\begin{array}{l}\text { The effect of your hand } \\
\text { sanitizer or disinfectant } \\
\text { during breast feeding }\end{array}$ & 57 & $11.22 \%$ & 129 & $25.39 \%$ & 64 & $12.60 \%$ & 113 & $22.24 \%$ & 145 & $28.54 \%$ & 508 & 2.69 & 0.000 \\
\hline $\begin{array}{l}\text { The effect of your } \\
\text { sanitizer or disinfectant } \\
\text { on children }\end{array}$ & 76 & $16.03 \%$ & 132 & $27.85 \%$ & 88 & $18.57 \%$ & 80 & $16.88 \%$ & 98 & $20.68 \%$ & 474 & 3.02 & 0.000 \\
\hline $\begin{array}{l}\text { The effect of your } \\
\text { sanitizer or disinfectant } \\
\text { on Elderly }\end{array}$ & 78 & $15.63 \%$ & 120 & $24.05 \%$ & 74 & $14.83 \%$ & 108 & $21.64 \%$ & 119 & $23.85 \%$ & 499 & 2.86 & 0.000 \\
\hline $\begin{array}{l}\text { How to deal with } \\
\text { sanitizer or disinfectant } \\
\text { poisoning }\end{array}$ & 71 & $13.81 \%$ & 110 & $21.40 \%$ & 81 & $15.76 \%$ & 122 & $23.74 \%$ & 130 & $25.29 \%$ & 514 & 2.75 & 0.000 \\
\hline First aid when poisoning & 71 & $14.29 \%$ & 128 & $25.75 \%$ & 79 & $15.90 \%$ & 106 & $21.33 \%$ & 113 & $22.74 \%$ & 497 & 2.88 & 0.000 \\
\hline \multicolumn{14}{|l|}{ Answered } \\
\hline Skipped & & & & & & & & & & & & & \\
\hline
\end{tabular}

\begin{tabular}{|c|c|c|c|c|c|c|c|c|c|c|c|c|c|}
\hline \multirow{2}{*}{$\begin{array}{l}\text { Store the sanitizer or } \\
\text { disinfectant at room } \\
\text { temperature }\end{array}$} & \multicolumn{2}{|c|}{$\begin{array}{l}\text { Complete } \\
\text { information }\end{array}$} & \multicolumn{2}{|c|}{$\begin{array}{l}\text { Incomplete } \\
\text { information }\end{array}$} & \multicolumn{2}{|c|}{$\begin{array}{c}\text { Weak } \\
\text { information }\end{array}$} & \multicolumn{2}{|c|}{$\begin{array}{l}\text { I do not have } \\
\text { information }\end{array}$} & \multicolumn{2}{|c|}{$\begin{array}{l}\text { I do not need } \\
\text { this information }\end{array}$} & \multirow{2}{*}{$\begin{array}{l}\text { Total } \\
393\end{array}$} & \multirow[b]{2}{*}{3.91} & \multirow{2}{*}{$\begin{array}{c}p \text {-value } \\
0.000\end{array}$} \\
\hline & $39.95 \%$ & 157 & $28.75 \%$ & 113 & $16.54 \%$ & 65 & $12.21 \%$ & 48 & $2.54 \%$ & 10 & & & \\
\hline storage in a refrigerator & $17.14 \%$ & 66 & $27.79 \%$ & 107 & $17.66 \%$ & 68 & $31.95 \%$ & 123 & $5.45 \%$ & 21 & 385 & 3.19 & 0.000 \\
\hline $\begin{array}{l}\text { storage the Sanitizer or } \\
\text { disinfectant exhibition } \\
\text { of light }\end{array}$ & $26.34 \%$ & 103 & $26.60 \%$ & 104 & $17.39 \%$ & 68 & $26.34 \%$ & 103 & $3.32 \%$ & 13 & 391 & 3.46 & 0.000 \\
\hline $\begin{array}{l}\text { How to deal with } \\
\text { expired Sanitizer or } \\
\text { disinfectant }\end{array}$ & $26.09 \%$ & 102 & $21.99 \%$ & 86 & $17.90 \%$ & 70 & $29.41 \%$ & 115 & $4.60 \%$ & 18 & 391 & 3.36 & 0.000 \\
\hline $\begin{array}{l}\text { Sanitizer or disinfectant } \\
\text { prices in general }\end{array}$ & $25.32 \%$ & 100 & $33.42 \%$ & 132 & $19.75 \%$ & 78 & $17.47 \%$ & 69 & $4.05 \%$ & 16 & 395 & 3.58 & 0.000 \\
\hline $\begin{array}{l}\text { Insurance coverage of } \\
\text { your hand sanitizer }\end{array}$ & $12.37 \%$ & 48 & $25.00 \%$ & 97 & $18.56 \%$ & 72 & $35.31 \%$ & 137 & $8.76 \%$ & 34 & 388 & 2.97 & 0.000 \\
\hline $\begin{array}{l}\text { Insurance coverage of } \\
\text { your disinfectant }\end{array}$ & $13.59 \%$ & 53 & $24.87 \%$ & 97 & $16.67 \%$ & 65 & $34.87 \%$ & 136 & $10.00 \%$ & 39 & 390 & 2.97 & 0.000 \\
\hline \multicolumn{14}{|l|}{ Answered } \\
\hline Skipped & & & & & & & & & & & & & \\
\hline
\end{tabular}




\begin{tabular}{|l|c|c|}
\hline Table 6: Sources of information about hand sanitizer or disinfectant. \\
\hline Answer Choices & \multicolumn{2}{|c|}{ Responses } \\
\hline Health practitioners & 174 & $46.15 \%$ \\
\hline Drug Bulletin & 154 & $40.85 \%$ \\
\hline Relatives and friends & 116 & $30.77 \%$ \\
\hline Internet & 243 & $64.46 \%$ \\
\hline The drug information center at the hospital & 66 & $17.51 \%$ \\
\hline Awareness lectures in a hospital & 50 & $13.26 \%$ \\
\hline Awareness lectures primary healthcare center & 53 & $14.06 \%$ \\
\hline Healthcare care awareness events at the market & 58 & $15.38 \%$ \\
\hline Medical doctor & 40 & $10.61 \%$ \\
\hline Other (please specify) & 6 & $1.59 \%$ \\
\hline Answered & $\mathbf{3 7 7}$ & \\
\hline Skipped & $\mathbf{2 5}$ & \\
\hline
\end{tabular}

Factors influencing the Public knowledge of public about contraindications of hand sanitizer and disinfectants

Various factors affected the knowledge of the public about contraindications of sanitizers and disinfectants during COVID-19. According to our results, most of the factors did not affect the knowledge of storage, with a non-statistically significant difference $(p>0.05)$. However, one factor that affected the knowledge of contraindications was the healthcare practitioner as the profession. Responders with nonhealthcare professions showed the highest score (2.7999) than those of healthcare professions (2.4204), with statistically significant differences $(p=0.000)$. Next, the relationship between public knowledge about contraindications of sanitizers and disinfectants during COVID-19 and factors affecting it was analyzed. Based on the multiple regression analysis, there was a weak relationship $(R=0.246$ with $p=0.002)$ between the public's knowledge about sanitizers and disinfectants' contraindications. Four out of seven factors showed non-significant differences $(p>0.05)$. However, age explained $11.1 \%$, and educational level explained $12.4 \%$ of the negative relationship. Moreover, healthcare professionals or otherwise responders described $21.5 \%$ of the positive relationship with knowledge about contraindications of sanitizers and disinfectants with a statistically significant difference $(p=0.042,0.029$, and 0.000$)$ in age educational level and healthcare professional respectively). The nonexistence of multi-collinearity verified the relationship with the current position factor with VIF of $1.113,1.211$, and 1.123, respectively, which is less than 3 or 5 as an acceptable number of VIF. ${ }^{32-34}$ (Table 8).

\section{Factors influencing the Public knowledge of storage of hand sanitizer and disinfectants}

Various factors affected the knowledge of storage of sanitizers or disinfectants during COVID-19, which includes location, nationality, gender, age, qualification, occupational status, and whether the responders were healthcare professionals. According to the results, most of the factors did not affect the knowledge of storage, and the differences were non-statistically significant $(p>0.05)$. However, a single factor affected the knowledge of storage, which is if the responder was a healthcare professional or not. The responder with healthcare professionals showed a higher score (3.5609) than that of non-healthcare professionals, with a statistically significant difference $(p=0.000)$. The relationship between the knowledge of storage of sanitizers and disinfectants during COVID-19 was analyzed by multiple regression analysis. According to the results, there was a weak relationship ( $R=0.219$ with $p=0.015$ ) between the knowledge of storage of sanitizers and disinfectants and factors affecting it. Six out of seven factors did not show any significant difference $(p>0.05)$. However, a single factor (i.e., the responder being the healthcare professional or not) explained $19.3 \%$ of the negative relationship with the knowledge of the public about the storage of sanitizers and disinfectants, with a statistically significant difference $(p=0.001)$. The non-existence of multi-collinearity verified the relationship with the current position factor with a VIF of 1.124, which is less than 3 or 5 as an acceptable number of $\operatorname{VIF}^{32-34}$ (Table 9).

\section{DISCUSSION}

Hand sanitizers and disinfectants are playing an active role in controlling the pandemic. ${ }^{2,6,7}$ In general, they prevent diseases transmission. ${ }^{2,6,7}$ Sanitizers and disinfectants contain various types of chemicals such as alcohol, phenols, and quaternary ammonium chloride. ${ }^{8-11}$ These chemicals can be used daily on soft and hard surfaces. ${ }^{2,6,7}$ Each class of disinfectant has a unique indication, adverse effect, contraindication, and storage condition. ${ }^{8-11}$ Public and patients must know these elements to prevent themselves from drug-related problems and infection. 
Table 7: Multiple regression of Factors with the General knowledge of sanitizer or disinfectant during used covid-19. ${ }^{a}$

\begin{tabular}{|c|c|c|c|c|c|c|c|c|c|c|c|c|c|c|}
\hline \multirow{2}{*}{\multicolumn{2}{|c|}{ Model }} & \multirow[b]{2}{*}{$\mathbf{R}$} & \multirow[b]{2}{*}{$\begin{array}{c}\mathbf{R} \\
\text { Square }\end{array}$} & \multirow[b]{2}{*}{$F$} & \multirow[b]{2}{*}{ Sig. } & \multicolumn{2}{|c|}{$\begin{array}{l}\text { Unstandardized } \\
\text { Coefficients }\end{array}$} & \multirow{2}{*}{$\begin{array}{c}\begin{array}{c}\text { Standardized } \\
\text { Coefficients }\end{array} \\
\text { Beta } \\
\end{array}$} & \multirow[b]{2}{*}{$\mathbf{t}$} & \multirow[b]{2}{*}{ Sig. } & \multicolumn{2}{|c|}{$\begin{array}{c}95.0 \% \text { Confidence } \\
\text { Interval for B }\end{array}$} & \multicolumn{2}{|c|}{$\begin{array}{l}\text { Collinearity } \\
\text { Statistics }\end{array}$} \\
\hline & & & & & & B & $\begin{array}{l}\text { Std. } \\
\text { Error }\end{array}$ & & & & $\begin{array}{l}\text { Lower } \\
\text { Bound }\end{array}$ & $\begin{array}{l}\text { Upper } \\
\text { Bound }\end{array}$ & Tolerance & VIF \\
\hline \multirow[t]{7}{*}{1} & (Constant) & \multirow[t]{7}{*}{$.397^{b}$} & \multirow[t]{7}{*}{.157} & \multirow[t]{7}{*}{9.439} & \multirow[t]{7}{*}{$.000^{\mathrm{b}}$} & 2.430 & 0.575 & & 4.229 & 0.000 & 1.300 & 3.561 & & \\
\hline & Locations & & & & & 0.035 & 0.046 & 0.039 & 0.765 & 0.445 & -0.056 & 0.127 & 0.901 & 1.110 \\
\hline & Sector of work & & & & & -0.016 & 0.084 & -0.011 & -0.194 & 0.846 & -0.181 & 0.148 & 0.816 & 1.226 \\
\hline & Nationality & & & & & -0.195 & 0.247 & -0.039 & -0.792 & 0.429 & -0.680 & 0.290 & 0.970 & 1.031 \\
\hline & Gender & & & & & -0.146 & 0.160 & -0.048 & -0.915 & 0.361 & -0.461 & 0.168 & 0.850 & 1.176 \\
\hline & Educational level & & & & & 0.004 & 0.079 & 0.003 & 0.047 & 0.963 & -0.152 & 0.160 & 0.829 & 1.207 \\
\hline & $\begin{array}{l}\text { Are you from } \\
\text { a health care } \\
\text { professional }\end{array}$ & & & & & 1.201 & 0.155 & 0.401 & 7.749 & 0.000 & 0.896 & 1.506 & 0.891 & 1.123 \\
\hline
\end{tabular}

a. Dependent Variable: General knowledge of Sanitizer or disinfectant during used covid-19 a, Predictors: (Constant), Location, Site of work, Age, Nationality, Gender, Educational level, Are you from the health care professional (Medical Doctor- Dentist- Pharmacist- Nurse- Others),

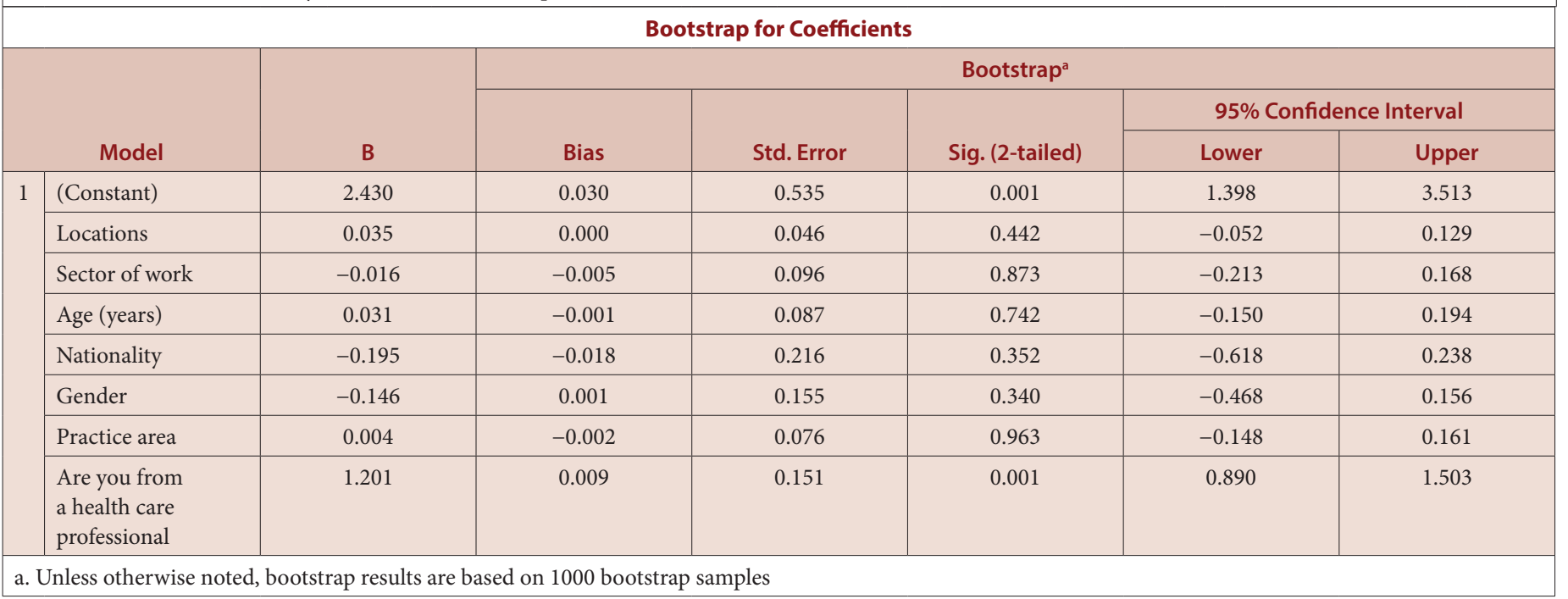

Therefore, in this study, we aimed to assess the knowledge of the public about sanitizers and disinfectants. In this cross-sectional study, we applied a self-administered electronic survey, which was validated with high reliability. The responders belonged to various regions, gender, age, qualifications, and jobs, which has also been reported by previous studies. ${ }^{22-24}$ The various demographic data is beneficial as most coverage of the society and population types. The average general knowledge of the public about sanitizers and disinfectants was found to be acceptable, which is better than that reported in previous studies. ${ }^{22-24}$ However, some vital information, such as the medication's generic name and its dosage form, is rare, which many people may not be interested in memorizing. Some of them may remember only the trade name. In this study, the average knowledge of the public about contraindications of sanitizers and disinfectants was found to be inadequate, which agrees with the results of previous studies. ${ }^{22,24}$ This result emphasizes that the public has information about adverse drug reactions and drug-drug interactions. However, the knowledge was weeks with the public about poisoning and related management of sanitizers and disinfectants and medications during breastfeeding and pregnancy. This information is highly required, especially during a pandemic. In this study, the average knowledge of the public about the storage of sanitizers and disinfectants war fair, which emphasizes the storage temperature requirement and medications prices similar to the previous study. ${ }^{24}$ This result might be related to the daily practice habits of the public, which is essential information.

On the contrary, the healthcare insurance coverage of sanitizer and disinfectants was rarely known by the public. The majority of the people did not ask about health insurance coverage or the cost of the products. The majority of the public obtained information about sanitizers and disinfectants from the internet and non-specified healthcare practitioner. They rarely asked pharmacists or physicians about it. Most people believe that it is easy for them to search about it on the internet, which can be quick and free of charge. However, the communications with the healthcare professionals might take some time or be more expensive to visit them. Besides, the internet may not provide accurate information most of the time, which might cause drug-related problems.

Various factors affected the general knowledge of the public about sanitizers and disinfectants. This result might be related to educational sessions provided to the public during the COVID-19 pandemic. Based on the occupational status, students showed the lowest level of knowledge, which was similar to a previous study. ${ }^{22}$ This result is expected because they needed more educational sessions on the use of sanitizers and disinfectants. In contrast, the findings showed the non-working 


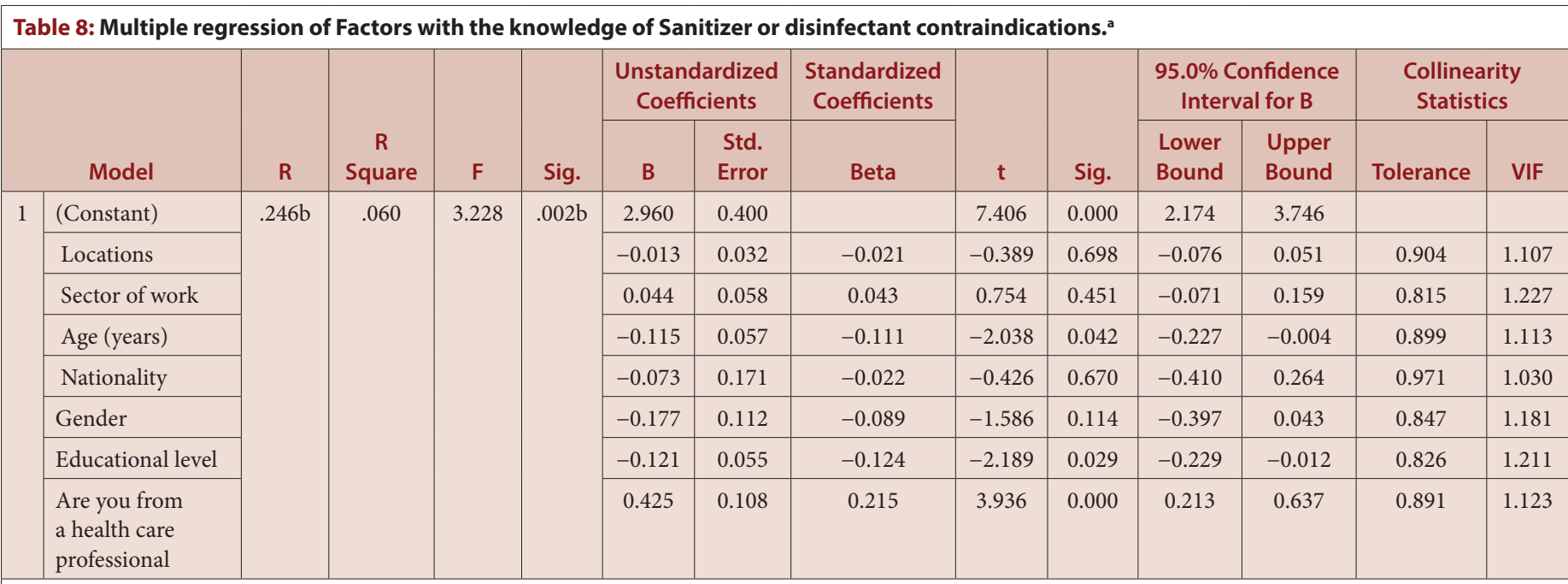

a. Dependent Variable: the knowledge of Sanitizer or disinfectant contraindications a, Predictors: (Constant), Location, Site of work, Age, Nationality, Gender, Educational level, Are you from the health care professional (Medical Doctor- Dentist- Pharmacist- Nurse- Others),

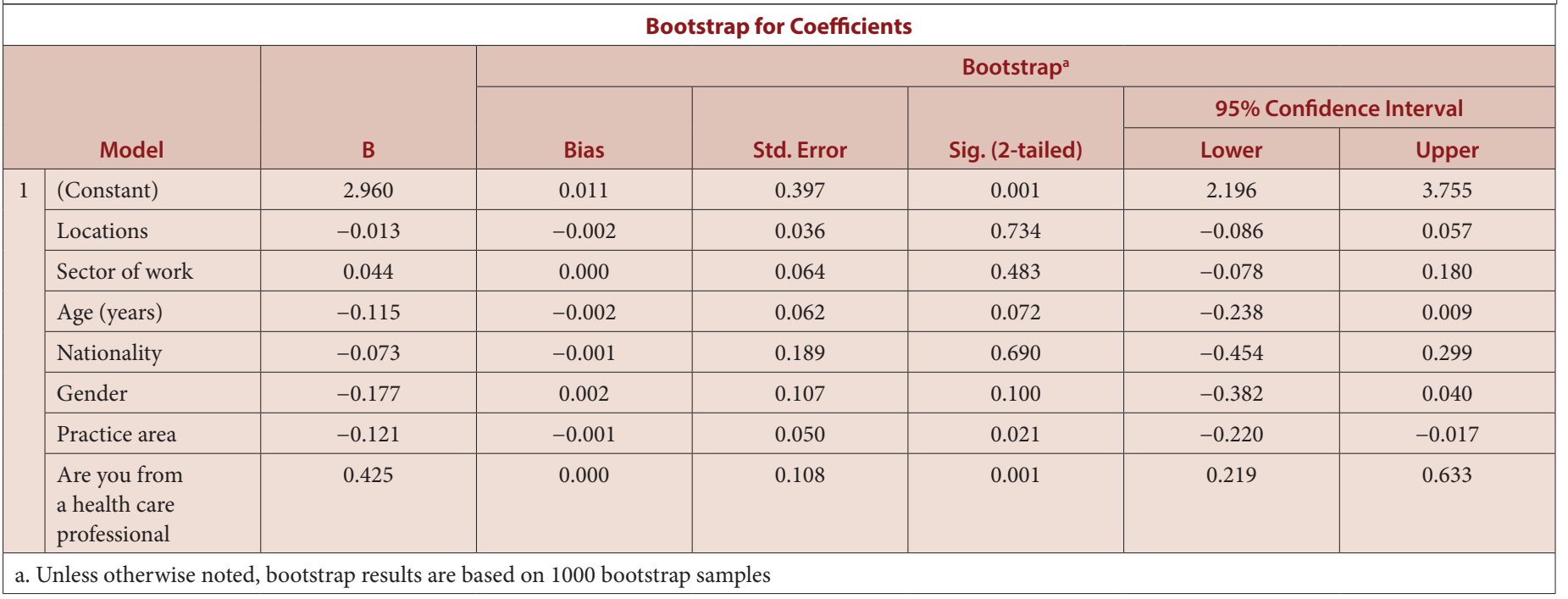

had higher knowledge than students. They might be graduates and had a good time reading about sanitizers and disinfectants. Moreover, non-working mainly in older people with gained higher degrees and experiences. Age affected the knowledge of sanitizers and disinfectants, emphasizing that those in the age group of less than 18 years had a higher score of knowledge than those in the age group of 18-29 years, which agrees with the results of a previous study. ${ }^{23}$ However, our results did not agree with some other studies, which might be related to the sample size of participants in the age group less than 18 years, which did not reflect the actual situation. Furthermore, participants who went to high school had higher knowledge than those with a bachelor's degree. Another factor that affected sanitizers and disinfectants' knowledge was whether the responders were healthcare professionals or otherwise. According to the results, non-healthcare professionals had higher knowledge than those healthcare professionals, which might be because they were busy working during COVID-19, and there was no time to read much about them. However, the busy schedule was not an excuse to increase the knowledge of sanitizer and disinfectants. Additional analysis showed a positive relationship between knowledge and healthcare professionals, which might depend almost $40 \%$ on the factors with increased knowledge.
The majority of factors did not affect the knowledge of contraindications of sanitizers and disinfectants. However, non-healthcare providers had higher knowledge of contraindications than healthcare professionals. That might be related to the fact that non-healthcare professionals were more serious about gaining more knowledge about contraindications. In addition, regression analysis showed that age affected the knowledge of sanitizers and disinfectants. The younger generation revealed more knowledge than that of older age. Moreover, the level of education negatively affected the knowledge. These results might be because those with lower degrees were more serious about getting information about sanitizer and disinfectants than those with higher academic qualifications.

Various factors affected the knowledge of storage of sanitizer and disinfectants. However, a single aspect affected the knowledge significantly. Healthcare providers had higher knowledge than nonhealthcare professionals. Moreover, there was a $19.3 \%$ reduction in knowledge, which might be related to work experience, and had lower knowledge of sanitizer and disinfectant. They did not or rarely read about sanitizer and disinfectant during the practice because of busy duties. We obtained conflicting results with regard to the type of knowledge of healthcare professionals. They had good general 


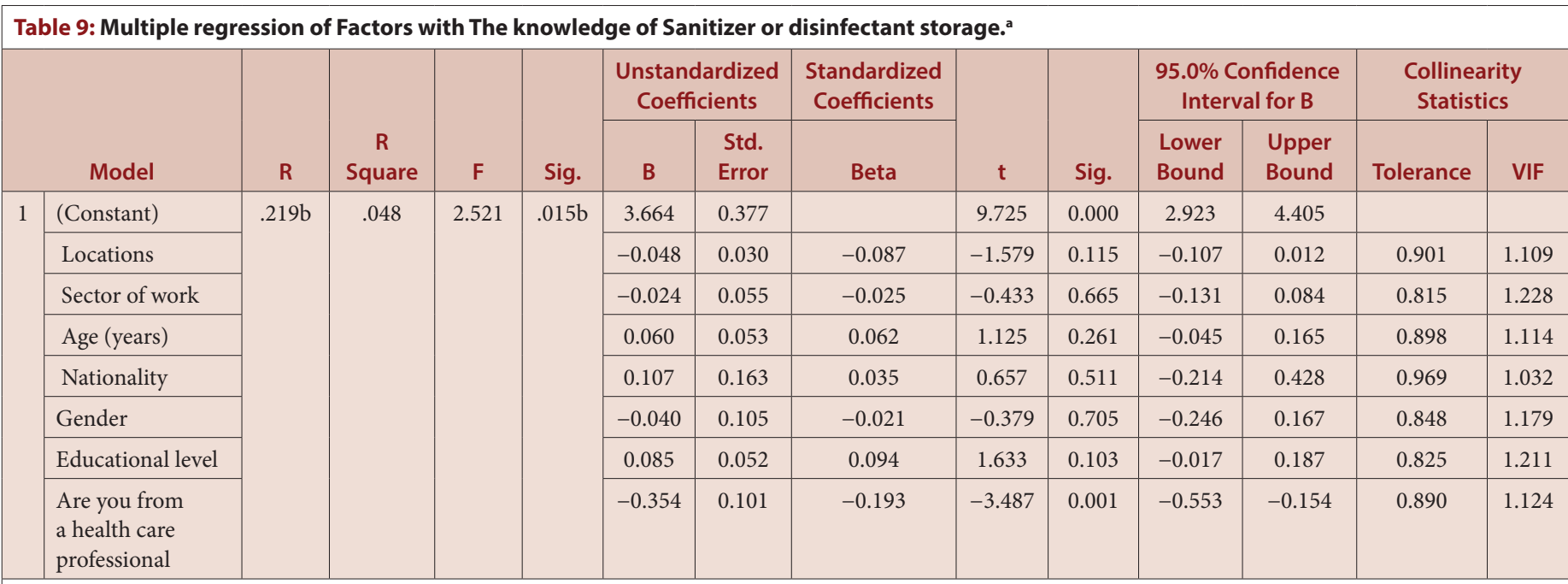

a. Dependent Variable: the The knowledge of Sanitizer or disinfectant storage a, Predictors: (Constant), Location, Site of work, Age, Nationality, Gender, Educational level, Are you from the health care professional (Medical Doctor- Dentist- Pharmacist- Nurse- Others),

\begin{tabular}{|c|c|c|c|c|c|c|c|}
\hline \multicolumn{8}{|c|}{ Bootstrap for Coefficients } \\
\hline \multirow{3}{*}{\multicolumn{2}{|c|}{ Model }} & \multirow[b]{3}{*}{ B } & \multicolumn{5}{|c|}{ Bootstrap ${ }^{a}$} \\
\hline & & & \multirow[b]{2}{*}{ Bias } & \multirow[b]{2}{*}{ Std. Error } & \multirow[b]{2}{*}{ Sig. (2-tailed) } & \multicolumn{2}{|c|}{ 95\% Confidence Interval } \\
\hline & & & & & & Lower & Upper \\
\hline \multirow[t]{8}{*}{1} & (Constant) & 3.664 & -0.024 & 0.342 & 0.001 & 2.935 & 4.319 \\
\hline & Locations & -0.048 & 0.000 & 0.032 & 0.142 & -0.113 & 0.014 \\
\hline & Sector of work & -0.024 & 0.002 & 0.063 & 0.688 & -0.149 & 0.100 \\
\hline & Age (years) & 0.060 & 0.003 & 0.056 & 0.281 & -0.051 & 0.174 \\
\hline & Nationality & 0.107 & 0.008 & 0.164 & 0.530 & -0.215 & 0.426 \\
\hline & Gender & -0.040 & 0.004 & 0.100 & 0.668 & -0.244 & 0.157 \\
\hline & Practice area & 0.085 & -0.004 & 0.047 & 0.080 & -0.017 & 0.176 \\
\hline & $\begin{array}{l}\text { Are you from } \\
\text { a health care } \\
\text { professional }\end{array}$ & -0.354 & 0.003 & 0.102 & 0.003 & -0.549 & -0.153 \\
\hline
\end{tabular}

knowledge and knowledge about storage. However, their knowledge about contraindications was poor. Moreover, responders with higher qualifications had poor knowledge. Therefore, all healthcare providers should increase their knowledge about sanitizers and disinfectants. ${ }^{35}$

\section{Limitation}

This study had an acceptable sample size, a high-reliability survey, and expert validation. However, it had some limitations. For example, the number of responders was different for different geographic locations, ages, occupations, and healthcare professionals. In addition, there were only a few studies to compare with them. Therefore, we recommend further studies with equal demographic information to overcome the drawbacks of this study.

\section{CONCLUSION}

The essential knowledge about sanitizers and disinfectants during the COVID-19 pandemic is acceptable in Saudi Arabia. However, the knowledge of the public about contraindications is inadequate. Most factors such as location, nationality, gender, and occupational status did not affect the understanding of sanitizers and disinfectants. However, healthcare professionals' age and membership might positively or negatively affect the knowledge of sanitizer and disinfectants. Therefore, we recommend providing educational sessions to the public about sanitizers and disinfectants to improve patient safety effectively.

\section{ACKNOWLEDGEMENT}

None.

\section{CONFLICT OF INTEREST}

The authors declare that there is no conflict of interest.

\section{Funding}

None

\section{Consent for Publications}

Informed consent was obtained from all the participants

\section{Ethical Approval}

This research is exempted from research and ethical committee or an institutional review board (IRB) approval.

https://www.hhs.gov/ohrp/regulations-and-policy/decisioncharts-2018/index.html 


\section{ABBREVIATIONS}

COVID-19: Coronavirus; MOH: Ministry of Health; KSA: Kingdom of Saudi Arabia; SPSS: Statistical package of social sciences; JASP: Jeffery's Amazing Statistics Program; STROBE: Strengthening the reporting of observational studies epidemiology.

\section{ORCID ID}

\section{Yousef Ahmed Alomi (iD https://orcid.org/0000-0003-1381-628X}

\section{REFERENCES}

1. Algaissi AA, Alharbi NK, Hassanain M, Hashem AM. Preparedness and response to COVID-19 in Saudi Arabia: building on MERS experience. J Infect Public Health. 2020;13(6):834-8. doi: 10.1016/j.jiph.2020.04.016, PMID 32451260.

2. Alomi YA, Al-Jarallah SM. Role of Pharmacist in the epidemic, pandemic, and emergency public health with an emphasis on coronavirus Disease (COVID-19). IJPCS. 2021;10(1):1-5. doi: 10.5530/ijpcs.2021.10.1

3. Varghese GM, John R, Manesh A, Karthik R, Abraham OC. Clinical management of COVID-19. Indian J Med Res. 2020;151(5):401-10. doi: 10.4103/ijmr. IJMR_957_20, PMID 32611911.

4. US Department of Health and Human Services, Centers for Disease Contro and Prevention. Infection control in healthcare personnel: Infrastructure and routine practices for occupational infection prevention and control services recommendations only. p. 1-8; 2019. Available from: https://www.cdc.gov/ infectioncontrol/pdf/guidelines/infection-control-HCP-recommendations-only-H. pdf [cited 22/11/2021]

5. Multidisciplinary management guidelines of Covid-19.

6. Ontario: Provincial Infectious Diseases Advisory Committee. Public health Ontario. Best practices for cleaning, disinfection, and sterilization of medical equipment/devices in all health care settings. $110 \mathrm{p}$.

7. Noorimotlagh Z, Mirzaee SA, Jaafarzadeh N, Maleki M, Kalvandi G, Karami C. A systematic review of emerging human coronavirus (SARS-CoV-2) outbreak: Focus on disinfection methods, environmental survival, and control and prevention strategies. Environ Sci Pollut Res Int. 2021;28(1):1-15. doi: 10.1007/ s11356-020-11060-z, PMID 33009614

8. Al-Sayah MH. Chemical disinfectants of COVID-19: An overview. J Water Health. 2020;18(5):843-8. doi: 10.2166/wh.2020.108, PMID 33095205.

9. Rutala WA, Weber DJ. Disinfection, sterilization, and control of hospital waste. In: Mandell, Douglas, editors, and Bennett's Principles and Practice of Infectious Diseases; 2014. p. 3294-3309.e1.

10. Rutala WA, Weber DJ, Weinstein RA, Pearson ML. Guideline for disinfection and sterilization in healthcare facilities; 2008. Miscellaneous inactivating agents [internet]. CDC [website. p. 2019]. Available from: http://www.cdc.gov/hicpac/ Disinfection_Sterilization/10_0MiscAgents.html [cited 22/11/2021].

11. Song $X$, Vossebein $L$, Zille A. Efficacy of disinfectant-impregnated wipes used for surface disinfection in hospitals: a review. Antimicrob Resist Infect Control. 2019:8:139. doi: 10.1186/s13756-019-0595-2, PMID 31452873.

12. Rutala WA, Weber DJ. Disinfection and sterilization in health care facilities: What clinicians need to know. Clin Infect Dis. 2004:39(5):702-9. doi: 10.1086/423182 PMID 15356786.

13. Sessa A, Di Giuseppe G, Albano L, Angelillo IF, Collaborative Working Group. An investigation of nurses' knowledge, attitudes, and practices regarding disinfection procedures in Italy. BMC Infect Dis. 2011 May 25;11:148. doi: 10.1186/1471-2334-11-148, PMID 21612613.

14. Stutz N, Becker D, Jappe U, John SM, Ladwig A, Spornraft-Ragaller P, et al Nurses' perceptions of the benefits and adverse effects of hand disinfection: alcohol-based hand rubs vs. hygienic handwashing: A multicentre questionnaire study with additional patch testing by the German Contact Dermatitis Research Group. Br J Dermatol. 2009 March;160(3):565-72. doi: 10.1111/j.1365 2133.2008.08951.x, PMID 19067700.

15. Khubrani A, Albesher M, Alkahtani A, Alamri F, Alshamrani M, Masuadi E. Knowledge and information sources on standard precautions and infection control of health sciences students at King Saud Bin Abdulaziz University for Health Sciences, Saudi Arabia, Riyadh. J Infect Public Health. 2018;11(4):546-9. doi: 10.1016/j.jiph.2017.10.013, PMID 29137958.
16. Qudeimat MA, Farrah RY, Owais Al. Infection control knowledge and practices among dentists and dental nurses at a Jordanian university teaching center Am J Infect Control. 2006:34(4):218-22. doi: 10.1016/j.ajic.2005.06.012, PMID 16679180.

17. Kim KM, Choi JS. Self-perceived competency of infection control nurses based on Benner's framework: A nationwide survey in Korea. Appl Nurs Res. 2015 May 1;28(2):175-9. doi: 10.1016/j.apnr.2014.09.010, PMID 25315139.

18. Peres $D$, Severo $M$, Ferreira MA. Knowledge, source of information, and perception of Portuguese medical students and junior doctors of infection control precautions. Am J Infect Control. 2016 December 1;44(12):1723-5. doi: 10.1016/j.ajic.2016.05.018, PMID 27499194.

19. Adegboye MB, Zakari S, Ahmed BA, Olufemi GH. Knowledge, awareness and practice of infection control by health care workers in the intensive care units of a tertiary hospital in Nigeria. Afr Health Sci. 2018 March 1;18(1):72-8. doi: 10.4314/ahs.v18i1.11, PMID 29977260.

20. Murtough SM, Hiom SJ, Palmer M, Russell AD. A survey of rotational use of biocides in hospital pharmacy aseptic units. J Hosp Infect. 2002 March;50(3):228-31. doi: 10.1053/jhin.2001.1155, PMID 11886201.

21. Sum ZZ, OW CJW. Community pharmacy response to infection control during COVID-19. A cross-sectional survey. Res Social Adm Pharm. 2021;17(1):1845-52. doi: 10.1016/j.sapharm.2020.06.014, PMID 33317763.

22. Gharpure R, Miller GF, Hunter CM, Schnall AH, Kunz J, Garcia-Williams AG. Safe Use and Storage of Cleaners, Disinfectants, and Hand Sanitizers: Knowledge, Attitudes, and Practices among US Adults during the COVID-19 Pandemic, May 2020. Am J Trop Med Hyg. 2020;104(2):496-501. doi: 10.4269/ajtmh.20-1119, PMID 33377450.

23. Shree MK, Rani S L, M. P. B. Knowledge and Awareness on the Role of Hand Sanitizer in Prevention of COVID 19 - A Questionnaire Survey. Int J Curr Res Rev. 2020;12(19):128-34. doi: 10.31782/IJCRR.2020.SP15.

24. Gharpure R, Hunter $C M$, Schnall $A H$, Barrett $C E$, Kirby $A E$, Kunz J, et al. Knowledge and Practices Regarding Safe Household Cleaning and Disinfection for COVID-19 Prevention - United States, May 2020. MMWR Morb Mortal Wkly Rep. 2020;69(23):705-9. doi: 10.15585/mmwr.mm6923e2. PMID 32525852

25. Charan J, Biswas T. How to calculate sample size for different study designs in medical research? Indian J Psychol Med. 2013:35(2):121-6. doi: 10.4103/02537176.116232, PMID 24049221.

26. Pourhoseingholi MA, Vahedi $M$, Rahimzadeh M. Sample size calculation in medical studies. Gastroenterol Hepatol Bed Bench. 2013;6(1):14-7. PMID 24834239.

27. Ezhumalai DG. How Big A Sample Do I Require?. Annals of SBV. 2017;6(1):39-41. doi: 10.5005/jp-journals-10085-6113.

28. Johnson TP, Wislar JS. Response rates and nonresponse errors in surveys [internet]. JAMA. 2012;307(17):1805-6. doi: 10.1001/jama.2012.3532, PMID 22550194

29. Von Elm E, Altman DG, Egger M, Pocock SJ, Gøtzsche PC, Vandenbroucke JP. The strengthening the reporting of observational studies in epidemiology (STROBE) statement: guidelines for reporting observational studies. PLOS Med. 2007:4(10):1623-7. doi: 10.1371/journal.pmed.0040296.

30. Von Elm E, Altman DG, Egger M, Pocock SJ, Gøtzsche PC, Vandenbroucke JP The Strengthening the Reporting of Observational Studies in Epidemiology (STROBE) statement: guidelines for reporting observational studies [internet] Vol. 370; 2007. Available from: http://www.thelancet.com. Available from: http:// www.plosmedicine.org [cited 22/11/2021]

31. Langan SM, Schmidt SA, Wing K, Ehrenstein V, Nicholls SG, Filion KB, et al. The reporting of studies conducted using observational routinely collected health data statement for pharmacoepidemiology (RECORD-PE). BMJ. 2018;363:k3532. doi: 10.1136/bmj.k3532, PMID 30429167.

32. Liao $D$, Valliant R. Variance inflation factors in the analysis of complex survey data. Surv Methodol. 2012;38(1):53-62.

33. Akinwande MO, Dikko HG, Samson A. Variance inflation factor: As a condition for the inclusion of suppressor variable(s) in regression analysis. Open J Stat. 2015;05(7):754-67. doi: 10.4236/ojs.2015.57075.

34. Thompson CG, Kim RS, Aloe AM, Becker BJ. Extracting the Variance Inflation Factor and Other Multicollinearity Diagnostics from Typical Regression Results. Basic Appl Soc Psych. 2017;39(2):81-90. doi: 10.1080/01973533.2016.1277529.

35. Octavia DR, Nurafifah D, Utami PR, Pangestu DP. The Effect of Counseling and Training on Public Knowledge about Making Hand sanitizer from Betel Extract. J Asian Multicult Res Med Heal Sci Study. 2021:2(2):8-16. 